\title{
A Walk in the Garden
}

I was always a lover despite the killings and I don't care what anyone says. When I was a boy in a Chicago apartment I wanted to be a farmer-never a cop, never a soldier, never president, always a farmer. I craved to put my hands into the soil and to make things grow. My parents, who had escaped brutal rural poverty, used to shake their heads over my demented ambition. I wound up teaching in a university and when I could not abide this crime against feeling, I wandered into a terrain I still lack a word for. They call it the street but often there is no pavement or any straight lines. But in my heart, I'm still a farmer looking for that good ground where I can make things grow.

I've just finished this book you are holding and I have fled from the work of it and the world of it. I am standing in the courtyard of a sacked hacienda in southern Chihuahua. I am but a few miles from the rancho where Pancho Villa retired after his years of steady killing. He also said he just wanted to farm. The ruined hacienda was built like a fort with a big gate, stout walls, its own granaries, stables, and living quarters, a private chapel safe and sacred within its bowels. No one who lived here ever thought any force could touch its brooding power. Now the roofs have caved in, the rains lick the adobes each year and crumble the soft bricks leaving fabriclike tears in the ramparts. Pigeons roost and shit in the 
family's former salon. Between 1910 and 1920, haciendas just like this one were gutted all over Mexico and left to die like flopping fish trapped and doomed by a receding flood. They did not see it coming; we never do.

In the center of the courtyard is a stone monument. Once it was topped by an obelisk but someone has smashed the top off and it now lies in the weeds at the base. The inscription is simple: a man's name, his birth date in 1897, his death date in April of 1919, and then a single phrase: CAYO EN LA DEFENSA DE ORDEN. He fell in the defense of order. And he fell just a few days shy of his twenty-second birthday. The world he died defending, a system of huge landholdings, big houses, feudal habits, and mass poverty, was one that had persisted for four hundred years or more. So, quite naturally, he probably thought it would last forever.

I was raised with the same sense of certainty, pride, and passion. My world was based on patriotism, hard work, and love of the land and the flag. I went to church. I never imagined being out of step with my government, my neighbors, or much else. I remember when in the twilight of the Eisenhower years Francis Gary Powers was shot down in his U-2 over the Soviet Union and my government denied that they had been flying spy missions and I believed them absolutely. I was young and foolish, no doubt, but it never occurred to me that my government would lie to me about such a weighty matter. I would like to say that I have changed a great deal since that time but I don't think I have. I am more a scorned lover than a bitter enemy. True, I no longer trust my government, nor any concentration of power, but I still at some level safe from my darkest thoughts believe in the promise of life and especially the promise of life on my native ground.

Which brings me back to the book I have fled, the one I left, as the Mexicans say, en otro lado, on the other side. It is my inquiry into what went wrong with my life, my country, and my times. It is a historical work without a footnote, a 
logical inquiry safe from expository sentences. I did not plan to write it and now that it is in type, I do not really know where it came from. Even the mind of someone who wants to be a farmer is subject to storms. When I was a boy one summer on my uncle's farm, I felt the lust of the July corn and come morning saw it all a dead, green mash from a wall of hail that had swept off the plains. I could tick off all the decisions I made while writing this book but they are really of no matter, save one: I thought it was better to feel what I saw than to weigh and measure and give number to the ferocity of this storm. What is explained can be denied but what is felt cannot be forgotten.

A couple of months ago, while I was deep in the psychosis of writing this book, a friend who had no idea what I was up to, gave me a favorite quotation that ran, "A person's life purpose is nothing more than to rediscover, through the detours of art, or love, or passionate work, those one or two images in the presence of which his heart first opened." Albert Camus wrote that and I believe every word of it. So I went into a strange garden of bloody orchids looking for the hopes that started my life.

And now, I am in this ruined hacienda staring at a memorial to another child of this era of blood and love. Last night, I was in a fancy hotel bar in Hidalgo del Parral, a city of about eighty thousand near the Durango border where Pancho Villa was cut down by assassins July 20, 1923-twenty-two years before my birth. There are few memorials to Villa in his favorite stomping ground of Chihuahua and almost none in the rest of Mexico. He is a man people seem almost afraid to remember. We actually think we get to judge him and decide who he was and whether he was as worthy as we are-tell me now your judgment of a rain forest, a blue whale, a hurricane. So, when I started talking to a table full of prosperous ranchers and businessmen in the bar, I asked them what people today thought of General Francisco Villa. One guy said, "Well, 
on the one hand, he took money from the rich and gave it to the poor and so some people still think he was okay. On the other hand, he used to bury people in anthills and pour marmalade on their heads." I was struck by the image of Pancho crossing the desert, his saddle bags stuffed with preserves, his bandolier heavy with jellies.

We will probably never find the real Pancho Villa smothered under our lies and myths. (How many people know he did not drink and never smoked and believed he was unfit to be the ruler of Mexico?) But we do know he tried to make a revolution and that when he died, he was trying to forge a communitarian community. And he liked the ladies, lots of the ladies. I suspect he died an optimist, thinking a better world was just over the next hill or year or battle. The boy who died defending his hacienda and order and a world of brutal slavery four hundred years stale probably lacked Villa's hopes for a better day. That is why his ancestral hacienda is now a ruin and Villa is still so alive out there in llanos and sierras and desiertos that people fear to mention his nameeven though the name he is remembered by was an alias.

I am an optimist myself, despite all the killings and the desert springs with bad water. I wrote this book because I had a simple, straightforward idea-we've been in a long war and we've lost that war and the war has poisoned us and our ground. If we admit these facts, we might be able to survive. If we don't, it really won't matter if we survive because we will be functionally dead. Pick up any newspaper, our obituary is everywhere on the pages. I am a member of the last generation that will ever confuse the idea of progress with the accumulation of more and more material things. I may be of the last generation that will be able to say the word progress without a tone of mockery.

Now I dream of the soft touch of women, the songs of birds, the smell of soil crumbling between my fingers, and the brilliant green of plants that I diligently nurture. I am 
looking for land to buy and I will sow it with deer and wild pigs and birds and cottonwoods and sycamores and build a pond and the ducks will come and fish will rise in the early evening light and take the insects into their jaws. There will be paths through this forest and you and I will lose ourselves in the soft curves and folds of the ground. We will come to the water's edge and lie on the grass and there will be a small, unobtrusive sign that says, THIS IS THE REAL WORLD, MUCHACHOS, AND WE ARE ALL IN IT.-B. TRAVEN. I am not making this up, it will all really happen, it is already happening. Like Villa, I just want to be a farmer. I suspect almost everyone does-Abraham Lincoln with the blood of half a million dripping from his big hands, Sylvia Plath with her head in the oven, both dreaming of the farm.

I don't know what to make of myself. A lot of the time, despite my deepest hungers and best efforts, I see blackness. But I am planting a young oak tree. I really am. It'll be here centuries after I'm gone. Assuming I choose to leave. 
THIS PAGE INTENTIONALLY LEFT BLANK 